\title{
Economic Effects of Lowering Crude Oil Prices on Saudi Arabia
}

\author{
Khaled N.Alrwis \\ SharafA. BakriAhamad
}

\author{
Adel M. Ghamen \\ Nageeb M. Ali Aldawdahi
}

Ph.D in Agricultural Economics - Institution: King Saud University

\begin{abstract}
Address: King Abdullah Ben Abdulaziz Food Security Chair, College of Food and Agricultural Sciences, Agricultural Economics, PO Box 2460, Riyadh 11451
\end{abstract}

\begin{abstract}
The study aims to measure the impact of lower crude oil prices in the international markets on the value of oil exports, resultant revenues, and government spending in Saudi Arabia, using the Recursive Model for the period 1990-2014. The study relies on secondary data issued by the Saudi Arabian Monetary Agency. It shows that due to an increase of $11.9 \%$ in the oil investment rate, the domestic production of crude oil has increased at an average annual growth rate of $0.9 \%$. Furthermore, due to the increase in the quantity and value of oil exports during the study period, revenue and government spending have increased at a rate of $9.9 \%$ and $6.9 \%$, respectively. This led to a $10 \%$ increase in the production and the spot price of crude oil, as well as the rate of growth of the global economy, driving anincrease in the Saudi exports of crude oil by $10.17 \%, 1.0 \%$, and $1.3 \%$, respectively. The study also shows that a $10 \%$ increase in the estimated value of oil exports led to an increase in government revenues by $9.32 \%$. The $10 \%$ increase in the estimated government revenues led to an increase in government spending by $6.05 \%$, while the value of public debt rose by $10 \%$, which led to a $12.3 \%$ reduction in government spending. In light of the continued application of the current petroleum policy and the fact that crude oil prices in international markets dropped to $\$ 35 / \mathrm{barrel}$, the expected decrease in export revenues, oil revenues, and government spending would be at a rate of $63.8 \%, 61.2 \%$, and $43.6 \%$, respectively. To preserve the oil reserves and reduce the financial losses incurred by Saudi Arabia, the study recommends the need to reconsider the current petroleum policy, a reduction in the production and export of crude oil, as well as a reduction in the expected supply and demand for crude oil in the international markets.
\end{abstract}

Keywords: crude oil, value of exports, government revenues, government spending, Saudi Arabia

\section{Introduction:}

Saudi Arabia is the most important petroleum-producing nation in the world. It holds $19 \%$ of the world reserves, accounts for $12 \%$ of global production and more than $20 \%$ of oil sales in international markets, and possesses a refining capacity of more than three million barrels per day. The oil policy of Saudi Arabia aims fora stability in the oil markets by increasing production to 12.5 million barrels a day, and keeps a spare productivity of not less than 1.5 million barrels per day. The UK is seeking cooperation with other producing countries inside OPEC and outside to ensure the availability of crude oil in the international markets. Although avoiding an excess in supply leads to a collapse in prices, producing countries suffered economic losses because of adherence to the stability policy. The OPEC countries could not control the prices, as their role was limited to achieving a balance between supply and 
demand in international markets (the Ministry of Petroleum and Minerals, 2015). Crude oil prices are affected by several factors, including the petroleum products' market conditions (gasoline and heating oil) in the United States, Japan, and the European Union, and the political developments in some producing countries, as well as the movement of speculators, investment in the oil sector, and the degree of cold weather during the winter. In light of the escalation in the production of shale oil in the US,return of the Libyan oil, China's slowing economic growth, and the lifting of financial and economic sanctions imposed on Iranby the European Union and the United States, oil prices are expected to continue to drop. All oil-producing countries will experience a loss on financial returns; GCC countries will lose more than $\$ 300$ billion.Thus, the impact on revenues and government spending for these countries will be enormous (IMF, 2015).

\section{Research objectives:}

This study aimed to measure the impact of lower crude oil prices in the international markets on the oil exports, revenues, and government spending of Saudi Arabia. This will be achieved by studying the following:

1. The current status of the production and export of crude oil for Saudi Arabia during the period 1990-2014.

2. The economic relationship between crude oil prices and the value of oil exports and revenues andgovernment spending during the study period.

3. The impact of lower crude oil prices on oil exports' value and revenues as well as government spending.

\section{The study methodology:}

In order to achieve its objectives, the study depended on econometric analysis. Specifically, it used the Recursive Model to study the impact of lower crude oil prices on the quantity and value of oil exports, the revenues earned, and the government spending during the period 1990-2014. The proposed model consists of the following equations:

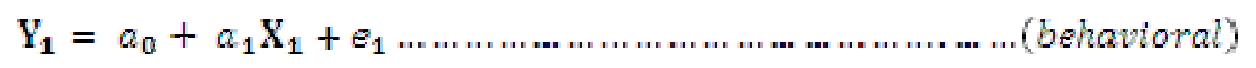

$\mathrm{Y}_{2}=b_{0}+b_{1} \hat{\mathrm{Y}}_{1}+b_{2} \mathrm{X}_{2}+b_{3} \mathrm{X}_{3}+\varepsilon_{2} \ldots \ldots \ldots \ldots \ldots \ldots \ldots$ (behavioral)

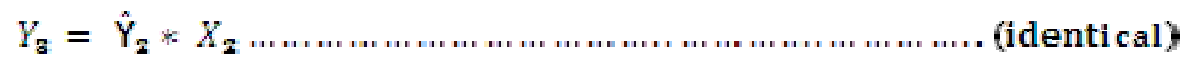

$\mathbf{Y}_{4}=\varepsilon_{0}+c_{1} \hat{Y}_{3}+e_{3} \ldots \ldots \ldots \ldots \ldots \ldots \ldots \ldots \ldots \ldots \ldots \ldots \ldots \ldots$ (behavioral $)$

$\mathrm{Y}_{5}=d_{0}+d_{1} \hat{\mathrm{Y}}_{4}+d_{2} \mathrm{X}_{4}+e_{4} \ldots \ldots \ldots \ldots \ldots \ldots \ldots \ldots \ldots$ (behavioral) variables:

It is clear from the proposed model that these equations include the following

1- Endogenous five variables are represented for all of the crude oil production in terms of million barrels $\left(\mathrm{Y}_{z}\right)$, and the amount of crude oil exports in million barrels $\left(\mathrm{Y}_{\mathrm{Z}}\right)$. The value of crude oil exports is represented in million dollars $\left(\mathbf{Y}_{Z}\right)$, the value of crude oil exports in million riyals $\left(\mathbf{Y}_{Z}\right)$, and government spending too in million riyals $\left(\mathbf{Y}_{\mathbf{Z}}\right)$.

2- Exogenous five variables are represented for all of the values of investments in the oil sector in million riyals $\left(\mathrm{X}_{z}\right)$. The average spot price of crude oil exports appear as dollar/barrel $\left(\mathrm{X}_{z}\right)$, and the rate of growth of the world economy as $\left(\mathrm{X}_{z}\right)$. The 


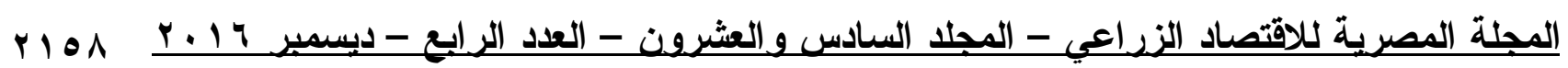

public debt appears in million riyals $\left(\mathrm{x}_{z}\right)$, in addition to random errors $\left(e_{1}, e_{3}, e_{3}, e_{4}\right)$. It is clear from the proposed model that crude oil production affects the amount of oil exports as well as the value of oil exports, which in turn affect government revenues and, consequently government spending. However, this is not reversed; it becomes a causal line in one direction and not in both directions. The internal variables' landmarks take on a triangle arrangement, the main diameter is equal to the unit, and there are no parameters above this diameter (Abdel-Kader, 1990). The proposed model was estimated through an equations sequential application of ordinary least squares (OLS). Lastly, the study relied on secondary data published in the annual reports issued by the Saudi Arabian Monetary Agency.

\section{Previous studies:}

Some previous studies have dealt with the economic effects of the volatility of crude oil prices in international markets. Aqeel (2003), in his book about the trip in the oil world, discusses fluctuations in crude oil prices, and explains that the price of crude oil increased from USD1.9/barrel in 1972 to USD35.69/barrel in 1980. In 1986, however, it decreased to USD13.01/barrel, and then increased to USD26.24/barrel in 2000. These movements were affected by the price fluctuations of crude oil production capacity of the oil surplus and policies of the International Energy Agency. Mneef (2011) explained that the production and prices of crude oil are characterized by sharp fluctuations, which were reflected in the national economy. The growth and the degree of diversification of the Saudi economy depend on the expected global supply and demand for crude oil. This has affected all of the oil investment; the production capacity, consumer interest, and the amount and value of oil exports; as well as the development spending of Saudi Arabia.

Mozainy (2013) studied factors affecting fluctuations in world oil prices, and suggested that world oil prices are influenced by a range of economic, geopolitical, climate, psychological, technical, and monetary factors, in addition to the scarcity factor. The soaring global oil prices are also affected by a range of economic, social, and political implications. The study recommended that the oil prices remain determined by the forces of supply and demand, and the mechanism of the free market will facilitate the pursuit of the stability of oil prices. Gulf States and OPEC must also cooperate in order to work hard on the pricing of oil against a basket of currencies rather than just the dollar, and this is suggested to avoid devaluation of the dollar against other currencies.

Marzouki (2015) stated in his lecture that the unexpected decline of the European economy and China led to a decline in crude oil prices, and it is because of this that the GCC incurred financial losses amounting to USD300 billion. Economic growth of countries belonging to the oil-exporting region was not affected due to the possession of financial reserves, which allowed them to maintain the level of spending. The International Monetary Fund expects the crude oil prices to rise to $\$ 72 /$ barrel in 2019. With the decline in crude oil prices, the exporting countries should reconsider the economic policies in the coming period and reduce government spending, in addition to improving the investment environment in order to attract 
investment and maintain the target rate of economic growth. Furthermore, Tim Callen (2015) stressed in his lecture that in light of the decrease in oil prices, the state should be directed to diversify sources of income and provide employment opportunities. The private sector should be made attractive to the Saudis through attention to training, and the development of the education sector to cope with the output of the labor market, in addition to the creation of genuine partnerships between the public and private sectors for the development of education and training. The International Monetary Fund (2015) suggested that the weakgrowth in the Eurozone and Russia has led to a decline in oil exports from the Middle East and North Africa, Afghanistan, Pakistan, the Caucasus, and Central Asia. Due to the decline in crude oil prices, Saudi Arabia will incur a loss of USD138 billion, representing $46.0 \%$ of the total value (USD300 billion) of the losses incurred by the Gulf Cooperation Council. With the decline in oil prices, the prioritization of capital spending and an increase in non-oil revenues through economic diversification and expansion of the productive base are necessary. Nashwan and Ghanem (2016) estimated a decrease in exports and losses resulting from a decrease in crude oil prices in the international market. In light of the decreasing average spot prices of crude oil from USD95.67/barrel to USD50/barrel, a decrease in Saudi exports of crude oil at a rate of value relative to a decrease of $48.1 \%$ is expected. In light of the continued application of the current petroleum policy, the value of financial losses would increase from USD128.12 billion, when the average crude oil price was USD50/barrel, to USD239.26 billion, when the average crude oil price would be USD10/barrel. The study recommended the need to reconsider the current petroleum policy, and to reduce the production and export of crude oil, which should promote a balance between the supply of and demand for crude oil in the international markets.

\section{Research Results}

\section{Saudi Arabia's current status of the production and export of crude oil:}

Studying the evolution of the Saudi Arabian production and export of crude oil during the period 1990-2014, it is clear from the data in table (1.2) that Saudi Arabia has the largest reserves of crude oil in the world, ranging from 260.34-266.58 billion barrels, with an annual average of 263.15 billion barrel. The reserve increased at a small annual growth rate of $0.09 \%$ during the study period. The domestic production of crude oil rangedfrom 2.34-3.57 billion barrels with an annual average of 3.08 billion barrel during the study period. Due to an $11.9 \%$ increase in the oil investment rate, crude oil's domestic production increased at an average annual growth rate of $0.9 \%$. rangedproduction relative to reserves of crude oil rangedfrom $0.9-1.34 \%$, an annual average of $1.17 \%$. Increased production relative to reserves of crude oil stood at an average annual growth rate of $0.9 \%$.

The amount of oil exports ranged from 1.64-2.78 billion barrels, with an annual average of 2.37 billion barrels during the study period. The volume of Saudi exports of crude oil also increased at an average annual growth rate of $1 \%$. The proportion of the amount of exports compared to the domestic production of crude oil was in the range of $70.2-81.4 \%$, with an annual average of $77.1 \%$ during the study period. Due to the allowed rate of growth in crude oil production, the ratio of the amount of 


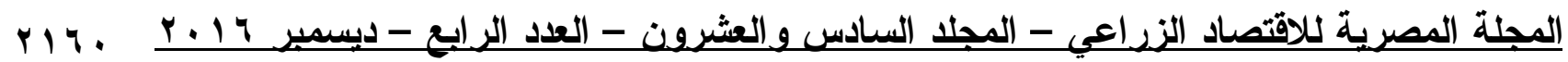

exports to the crude oil production did not achieve a significant increase during the period 1990-2014. Due to an increase in the quantity and value of oil exports during the study period, the revenue and government spending increased at a rate of $9.9 \%$ and $6.9 \%$, respectively.

Table (1): Descriptive analysis of the production of crude, crude export revenues, government expenditure,and public debt of Saudi Arabia during the period 1990-2014

\begin{tabular}{|l|c|c|c|c|c|}
\hline \multicolumn{1}{|c|}{ Statement } & Minimum & Maximum & Average & $\begin{array}{c}\text { Standard } \\
\text { deviation }\end{array}$ & $\begin{array}{c}\text { Coefficient of } \\
\text { variation\% }\end{array}$ \\
\hline $\begin{array}{l}\text { Production in million } \\
\text { barrels }\end{array}$ & 2340.50 & 3573.40 & 3077.93 & 299.73 & 9.74 \\
\hline Reserves in billion barrels & 260.34 & 266.58 & 263.15 & 1.177 & 0.67 \\
\hline $\begin{array}{l}\text { Production to reserve } \\
\text { ratio\% }\end{array}$ & 0.89 & 1.34 & 1.17 & 0.11 & 9.40 \\
\hline $\begin{array}{l}\text { Investments in the oil sector } \\
\text { in million riyals }\end{array}$ & 4234.0 & 70084.0 & 28913.8 & 24044.9 & 83.2 \\
\hline $\begin{array}{l}\text { Export quantity in million } \\
\text { barrels }\end{array}$ & 1642.42 & 2783.78 & 2376.53 & 257.91 & 10.85 \\
\hline $\begin{array}{l}\text { Proportion of exports to } \\
\text { production \% }\end{array}$ & 70.17 & 81.37 & 77.13 & 2.25 & 2.92 \\
\hline $\begin{array}{l}\text { Government revenues } \\
\text { million riyals }\end{array}$ & 114600.0 & 1247398.0 & 475005.3 & 382988.2 & 80.6 \\
\hline $\begin{array}{l}\text { Government spending in } \\
\text { million riyals }\end{array}$ & 122552.0 & 739156.0 & 271770.4 & 169335.9 & 62.3 \\
\hline Public debt in million riyals & 44260.0 & 685206.0 & 311575.3 & 205045.9 & 65.8 \\
\hline
\end{tabular}

Source: The Saudi Arabian Monetary Agency (2015 Fiftyone Annual Report.

Table 2: Statistical analysis of the evolution of production and exportof crude oil, revenues, and government expenditure, and public debt of Saudi Arabia during the period 1990-2014

\begin{tabular}{|c|c|c|c|c|}
\hline Statement & $\begin{array}{l}\text { Growth } \\
\text { rate }\end{array}$ & $F$ & $R^{2}$ & Equation \\
\hline $\begin{array}{l}\text { Production in } \\
\text { million barrels }\end{array}$ & 0.9 & 23.99 & 0.51 & $\begin{array}{r}\operatorname{Ln} \mathbf{Y}_{1}=7.902+0.009 T \\
(269.13)^{*}(4.90)^{*}\end{array}$ \\
\hline $\begin{array}{l}\text { Investments in the } \\
\text { oil sector in } \\
\text { million riyals }\end{array}$ & 11.9 & 222.04 & 0.91 & $\begin{array}{l}\operatorname{Ln} \mathbf{Y}_{2}=8.343+0.119 T \\
(70.20)^{*}(14.90)^{*}\end{array}$ \\
\hline $\begin{array}{c}\text { Reserve in billion } \\
\text { barrels }\end{array}$ & 0.09 & 466.23 & 0.95 & $\begin{array}{c}\operatorname{Ln} \hat{\mathbf{Y}}_{3}=5.561+0.0009 T \\
(9043.76)^{* *}(21.59)^{*}\end{array}$ \\
\hline $\begin{array}{l}\text { Production to } \\
\text { reserve ratio\% }\end{array}$ & 0.9 & 20.10 & 0.46 & $\begin{aligned} & \operatorname{Ln} \mathbf{Y}_{4}=0.038+0.009 T \\
&(1.30)^{n s}(4.48)^{*}\end{aligned}$ \\
\hline $\begin{array}{l}\text { Export quantity } \\
\text { in million barrels }\end{array}$ & 1.0 & 17.22 & 0.43 & $\begin{aligned} \operatorname{Ln} \hat{\mathbf{Y}}_{5}=7.634+0.01 T \\
(207.53)^{\mathrm{*} *}(4.15)^{\mathrm{s}}\end{aligned}$ \\
\hline $\begin{array}{l}\text { Proportion of } \\
\text { exports to } \\
\text { production } \\
\end{array}$ & 0.06 & 0.51 & 0.02 & $\begin{array}{r}\operatorname{Ln} \mathbf{Y}_{6}=4.337+0.0006 T \\
(352.00)^{8}+(0.72)^{n s}\end{array}$ \\
\hline $\begin{array}{l}\text { Government } \\
\text { revenues in } \\
\text { million riyals }\end{array}$ & 9.9 & 104.77 & 0.82 & $\begin{array}{c}\operatorname{Ln} \dot{P}_{7}=11.456+0.099 T \\
(78.88)^{* *}(10.24)^{* *}\end{array}$ \\
\hline $\begin{array}{l}\text { Government } \\
\text { spending in } \\
\text { million riyals }\end{array}$ & 6.9 & 178.88 & 0.89 & $\begin{array}{r}\operatorname{Ln} \hat{\mathbf{Y}}_{g}=11.462+0.069 T \\
(149.39)^{*}(13.37)^{-}\end{array}$ \\
\hline $\begin{array}{l}\text { Public debt in } \\
\text { million riyals }\end{array}$ & -9.5 & 10.17 & 0.49 & $\begin{aligned} \operatorname{Ln} \hat{\mathbf{Y}}_{9}= & 13.908-0.095 T+0.704 a r(1) \\
& (9.28)^{8 *}(-1.11)^{n s}(4.15)^{8 *}\end{aligned}$ \\
\hline
\end{tabular}

** Significant at 1\%probability, ns: not significant

Source: The Saudi Arabian Monetary Agency (2015). Fifty one Annual Report. 
Estimation of the proposed model for the study of relationship between crude oil prices and the value of oil exports, revenues, and government spending:

The behavioral equations of the proposed model depicted in table (3) showed a $10 \%$ increase in fixed investment in the oil sector, leading to a $7.7 \%$ increase in crude oil production. The $10 \%$ increase in the estimated production of crude oil, the average spot price of Saudi crude oil, and the rate of growth of the global economy led to an increase in Saudi exports of crude oil by $10.17 \%, 1.0 \%$, and $1.3 \%$, respectively. This also shows an increase in the estimated value of oil exports by $10 \%$, which led to an increase in government revenues by $9.32 \%$. The increase in estimated value of government revenues by $10 \%$ led to a $6.05 \%$ increase in government spending, while the value of public debt of Saudi Arabia increased by $10 \%$ and led to a reduction in government spending of $12.3 \%$. It also clear that behavioral equations of the proposed model, free of autocorrelation of residuals problem, according to the Breusch-Godfrey serial correlation LM test as there is no self-link in the chain.In contrast, according to the Arch Test, behavioral equations in the proposed model with a good efficiency in the data used to estimate the representation, according to indicators to measure the efficiency of the model, the most important inequality coefficient of Theil (U- Theil), which approached its value from zero (Table 4).

Table 3: Proposed model equations to study the impact of lower crude oil prices on the exports, revenues, and government spending of Saudi Arabia value during the period 1990-2014.

\begin{tabular}{|c|c|}
\hline $\begin{array}{ll}\text { Equation } \\
\end{array}$ & Statement \\
\hline $\begin{array}{l}\operatorname{Ln} \bar{Y}_{1}=7.264+0.077 \operatorname{Ln} X_{1} \\
(46.28)^{*} \cdot(4.89)^{*} \\
\qquad R^{2}=0.51 \quad F=23.88 \quad D . W=1.33\end{array}$ & Crude oil production \\
\hline $\begin{array}{l}\operatorname{Ln} \dot{Y}_{2}=-0.443+1.017 \operatorname{Ln} \hat{Y}_{1}+0.010 \operatorname{Ln} X_{2}+0.013 \mathrm{Ln} X_{\mathrm{a}} \\
(-10.08)^{*}(12.53)^{*}(3.16)^{*}(2.73)^{*} \\
R^{2}=0.89 F=56.63 \mathrm{D} . W^{*}=1.54\end{array}$ & Quantity of crude oil exports \\
\hline $\begin{array}{l}Y_{\mathrm{g}}=\dot{Y}_{\mathrm{g}} * X_{\mathrm{a}} \\
\mathrm{Ln} \hat{Y}_{4}=2.242+0.932 \mathrm{Ln} \hat{Y}_{\mathrm{a}} \\
\left(3.79 y^{*}(17.84)^{\circ *}\right. \\
R^{2}=0.93 F=318.29 \quad \text { D.W } W=2.34\end{array}$ & Value of government revenues \\
\hline $\begin{array}{l}\operatorname{Ln} \dot{Y}_{\overline{5}}=6.176+0.605 \operatorname{Ln} \hat{Y}_{4}-0.123 \operatorname{Ln} X_{4} \\
(6.54)^{* *}(14.22)^{* *}(-2.70)^{* *} \\
R^{2}=0.93 F=152.68 \text { D.W } W=1.19\end{array}$ & Government spending value \\
\hline
\end{tabular}

** Significant at $1 \%$ probability, * Significant at the level of $5 \%$ probability

Source: The Saudi Arabian Monetary Agency (2015 Fiftyone Annual Report.

Table (4): Indicators of the efficiency of the proposed model during the period 1990-2014

\begin{tabular}{|c|c|c|c|c|}
\hline \multicolumn{5}{|c|}{ Behavioral equations } \\
Fourth & Third & Second & First & Index \\
\hline 0.14 & 0.21 & 0.08 & 0.07 & Root Mean Souare Error (R.M.S.E.) \\
\hline 0.11 & 0.13 & 0.06 & 0.05 & Mean Ahsolute Error M.A.E.) \\
\hline 0.89 & 1.08 & 0.74 & 0.68 & Mean Absolute Percentage Error (M.A.P.E.) \\
\hline 0.006 & 0.008 & 0.005 & 0.004 & (U) Theil \\
\hline
\end{tabular}

Source: Collected and calculated from the behavioral equations of the model proposal mentioned in table (3). 
المجلة المصرية للاقتصاد الزراعي - المجلد السادس والعشرون - العدد الرابع - دبسمبر 17 . ب r r r

Measuring the impact of lower crude oil prices on oil exports, revenues, and government spending:

The impact of lower crude oil prices on the oil export value, revenues, and government spending of Saudi Arabia has been measured under the following assumptions:

1. The continued application of the current oil policy of Saudi Arabia, which targeted the stability of oil markets by increasing the production capacity of crude oil to 12.5 million barrels per day, that is, 3,550 million barrels annually.

2. The relative stability of the rate of growth of the global economy $(3.4 \%)$ as it was in 2014.

3. The continued decline of the average Saudi crude oil prices from USD95.67/barrel in 2014, even down to USD10/barrel.

4. Due to the lack of a significant decrease in the public debt of Saudi Arabia during the study period, the stability of the public debt amounting to 44.26 billion riyals, as it was in the year 2014, has been assumed.

It is clear from the data in table (5) that in the light of decreasing average spot prices of crude oil from USD95.67/barrel to USD35/barrel, the volume of Saudi exports of crude oil is expected to decrease from 2.7855 billion barrels, valued at USD266.49 billion, to 2.7577 billion barrels, valued at USD96.5 billion. Thus, the export value of crude oil is expected to drop at a rate of $63.8 \%$. In light of the lower average spot prices of USD10/barrel, the volume of Saudi exports of crude oil is expected to decrease to 2723.3 billion barrels, valued at USD27.23 billion dollars. Thus, the export value of crude oil is expected to drop at a rate of $89.8 \%$. With regard to the effect of decreasing average spot prices of crude oil from USD95.67/barrel to USD35/barrel on government revenues, it is clear that the government revenues are expected to decrease from 1072.57 billion riyals to 416.2 billion riyals, a relative decrease of $61.2 \%$. In light of lower average spot prices to USD10/barrel, government revenues are expected to decrease to 128.0 billion riyals, at a rate of $88.1 \%$. In conclusion, owing tothe decreasing average spot prices of crude oil from USD95.67/barrel to USD35/barrel, government spending is expected to decrease from 574.3 billion riyals to 323.9 billion riyals at a rate of $43.6 \%$. Ifthe average spot prices fallto USD10/barrel, government spending is expected to decrease to 158.7 billion riyals, at a rate of $72.4 \%$. 
Table (5): Estimates of the expected value for Saudi exports of crude oil and the value of revenues and government spending, given the decline in crude oil prices in international markets

\begin{tabular}{|c|c|c|c|c|c|c|c|c|c|}
\hline $\begin{array}{c}\text { Relative } \\
\text { rate of } \\
\text { decrease }\end{array}$ & $\begin{array}{l}\text { Government } \\
\text { spending in } \\
\text { million riyals }\end{array}$ & $\begin{array}{c}\text { Relative } \\
\text { rate of } \\
\text { decrease }\end{array}$ & $\begin{array}{l}\text { Government } \\
\text { revenues in } \\
\text { million riyals }\end{array}$ & $\begin{array}{c}\text { Relative } \\
\text { rate of } \\
\text { decrease }\end{array}$ & $\begin{array}{c}\text { Export } \\
\text { value in } \\
\text { million US } \\
\text { dollars }\end{array}$ & $\begin{array}{c}\text { Export } \\
\text { quantity } \\
\text { in million } \\
\text { barrels }\end{array}$ & $\begin{array}{c}\text { Growth } \\
\text { rate of the } \\
\text { global } \\
\text { economy }\end{array}$ & $\begin{array}{l}\text { Crude oil } \\
\text { production } \\
\text { in million } \\
\text { barrels }\end{array}$ & $\begin{array}{c}\text { Crude oil } \\
\text { prices in } \\
\text { dollars/ } \\
\text { barrel }\end{array}$ \\
\hline- & $O V \leq Y \backslash \leq, q$ & - & 1.VY० & - & หร ะ & $r \vee \wedge \bullet, 0$ & $r, \varepsilon$ & roo. & $90,7 V$ \\
\hline$r \cdot, q$ & 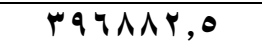 & $\varepsilon \theta, V$ & 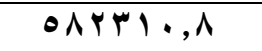 & $\varepsilon \wedge, 1$ & I rAMVQ,r & YVIV,0 & $r, \varepsilon$. & roo. & 0. \\
\hline$r \varepsilon, q$ & PVPVIq, & $0 \cdot, 1$ & OYVMr., r & $\Delta r, r$ & $I Y \leq \varepsilon, 7, V$ & YVY & $r, \varepsilon$. & roo. & $\leqslant 0$ \\
\hline$r q, 1$ & $15 \leqslant 9019,9$ & $07,$. & $\varepsilon \vee \backslash ৭ \wedge \wedge, 7$ & $\theta \wedge, 7$ & $11 . \leqslant 0 \%, 0$ & $r \vee Y 1, r$ & r, $\varepsilon$. & Moo. & $\varepsilon$. \\
\hline$\varepsilon \Psi, 7$ & PrYqro,q & $71, Y$ & \&। TrYq,. & $7 \mu, \Lambda$ & 97018,9 & $r V \otimes V, V$ & r, \&. & roo. & ro \\
\hline$\varepsilon \wedge, \mu$ & Yq VV. I, \& & 97,8 & $r q \ldots 1 \wedge, r$ & $79,$. & AY & YVOY, \& & $r, \varepsilon$. & roo. & r. \\
\hline Or, \& & 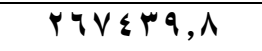 & $\mathrm{VI}, \mathrm{V}$ & $r \cdot r Y \leq Y, Y$ & $V \varepsilon, Y$ & $\neg \wedge \vee \cdot 9, \wedge$ & $P V \leqslant \Lambda, \varepsilon$ & $r, \varepsilon$. & roo. & Yo \\
\hline $09,$. & YMOOYE, \& & VV,I & $r \leq 0 \vee q 1,1$ & Vq, \& & $\theta \leq \wedge \leq \theta, r$ & $r V \leq r, r$ & $r, \varepsilon$. & roo. & $r$. \\
\hline $70, Y$ & $19994 Y, 0$ & $\Lambda Y, 0$ & $1 \wedge \vee \leqslant \wedge 1,7$ & $\Lambda \varepsilon, 7$ & $\leqslant 1 \cdot 10,1$ & PVTE, \& & r, \&. & roo. & 10 \\
\hline VY, \& & $10 \wedge V \cdot \Lambda, r$ & $\wedge \wedge, 1$ & I rVqqV,I & $\wedge q, \wedge$ & PVYMT,Y & YVYr, & $\Gamma, \varepsilon$. & roo. & 1. \\
\hline
\end{tabular}

Source: Calculated from the research hypotheses as proposed in the model mentioned in table (3). 


\section{Recommendations:}

Saudi Arabia committed to apply the current petroleum policy in order to maintain the stability of crude oil in the international markets, and to increase its production capacity to 12.5 million barrels a day. In 2015 , crude oil prices declined to USD35/barrel in the international markets, triggering an expected decrease in exports value, oil revenues, and government spending at a rate of $63.8 \%, 61.2 \%$, and $43.6 \%$ respectively. To preserve oil reserves and control the financial losses incurred by Saudi Arabia, the study recommends the need to reconsider the current petroleum policy, reduce the production and export of crude oil, and strike a balance between the expected supply and demand for crude oil in the international markets.

\section{References:}

1. Tim Callen (2015). Saudi economy, Workshop (Economics of the Middle East in light of the international changes and the role of the private sector). The Chamber of Commerce and Industry in Riyadh, February.

2. International Monetary Fund, the Middle East, and Central Asia Management (2015). Ways to cope with the decline in oil prices in the context of falling demand in the Middle East and Central Asia. 21January.

3. Abdul Qadir, Abdul Qader Mohammed (1990). Methods of measuring economic relations with Computer mail applications. Egyptian universities press, Alexandria, Egypt.

4. Al-Aqil, Khalid bin Mansour (2003). Journey in the oil world, international petroleum issues. The first edition, King Fahd National Library, Riyadh, pp 5-54.

5. Marzouki, Raja (2015). IMF's role in the Middle East, workshop (the economies of the Middle East in light of the international changes and the role of the private sector), the Chamber of Commerce and Industry in Riyadh, February.

6. Muzaini, Imad al-Din Muhammad (2013). Factors that influenced the fluctuations in world oil prices. The magazine of Al-Azhar University in Gaza, a series of Humanities, Vol. 15, No. 1, pp 319-346.

7. Muneef, Majed Abdullah (2011). Saudi economy and the future of energy. The twenty -sixth session, the National Festival for Heritage and Culture, Janadriah, April 18.

8. Saudi Arabian Monetary Agency (2015). FiftyoneAnnual Report.

9. Nashwan, Othman bin Saad, and Adel Mohammed KhalifaGhanem (2016). Estimating exports and losses resulting from the decline in crude oil prices, Saudi Arabia's, research presented to post.

10.Al-Naimi, Ali Ibrahim (1995). Petroleum and mining policy of the Kingdom of Saudi Arabia. U.S Saudi Arabian Business Council.The second annual meeting, Riyadh, October 28.

11. The Ministry of Petroleum and Mineral Resources (2015). Saudi Arabia petroleum policy, the website of the Ministry,www.mopm.gov.sa.

12.Hirschman, A. (1964). The paternity of an index. American Economic Review 54(4-6), pp 761-762.

13.Lapteacru, I. (2012). Assessing lending market concentration in Bulgaria: The application of a new measure of concentration. The Journal of Comparative Economics, Vol. 9, No. 1, pp 79-102. 
الآثار الاقتصادية الناجمة عن إنخفاض أسعار النفط الخام للمملكة العربية السعودية

عادل محمد خليفة غانم

نجيب محمد علي الدودحي

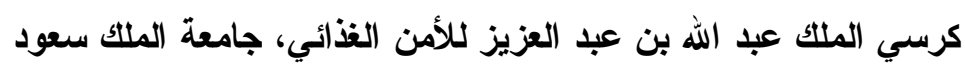

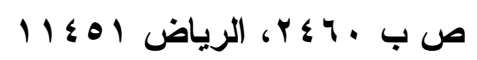

خالا بن نهار الرويس

شرف الدين بكري أحمد

الملخص:

إستهدف البحث قياس أثز إنخفاض أسعار النفط الخام في الأسواق الدولية على قيمة الصادر ات

النفطية و الإير ادات و الإنفاق الحكومي للمملكة العربية السعودية، وذلك بإستخدام Recursive Model خلال

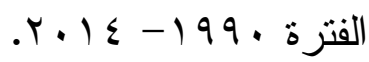

و إعتمدت الدر اسة على البيانات الثانوية التي تصدرها مؤسسة النقد العربي السعودي. وأوضحت

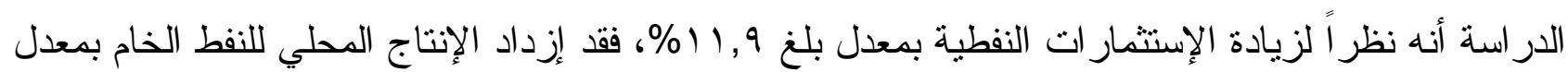
نمو سنوي بلغ 9, ••\%. ونظراً لزيادة كمية وقيمة الصادرات النفطية خلال فترة الدراسة، فقد إزدادت الإير ادات و الإنفاق الحكومي بمعدل بلغ 9,9\%، 9, ؟\% لكل منهما على التو الي. كما أن زيادة كل من الإنتاج و السعر الفوري للففط الخام ومعدل نمو الإقتصاد العالمي بنسبة • (1\%، تؤدي إلى زيادة كمية الصادر ات

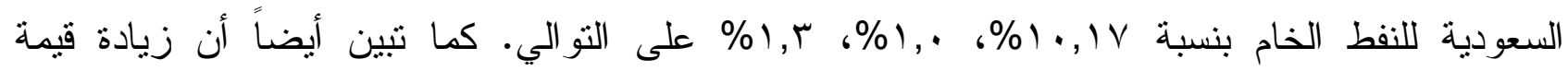
الصادر ات النفطية المقدرة بنسبة ، (\%) تؤدي إلى زيادة قيمة الإير ادات الحكومية بنسبة بس,و\%٪. كما أن زيادة قيمة الإير ادات الحكومية المقدرة بنسبة · (1\%، نؤدي إلى زيادة الإنفاق الحكومي بنسبة ه. ,7\%، في حين أن زيادة قيمة الدين العام للمملكة العربية السعودية بنسبة ، (\%)، تؤدي إلى إنخفاض الإنفاق الحكومي بنسبة r, r \% . وفي ظل الإستمرار في تطبيق السياسة البترولية الحالية و إنخفاض أسعار النفط الخام في الأسواق الدولية إلى هب دو لار/ برميل، يتوقع تتاقص كل من قيمة الصادرات النفطية و الإير ادات و الإنفاق

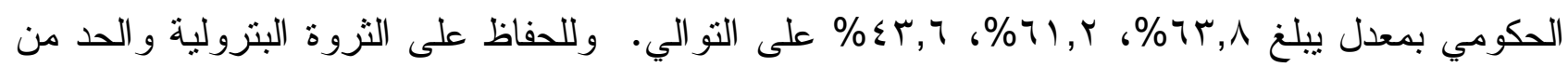
الخسائر المالية التي تتكبدها المملكة العربية السعودية، توصي الدراسة بضرورة إعادة النظرفي السياسة البترولية الحالية، وذلك من خلال تقليل إنتاج وتصدير النفط الخام، و الموازنة بين العرض و الطلب المتوقع لون للنفط الخام في الأسو اق الدولية.

كلمات دالة: النفط الخام، قيمة الصادرات، الإيرادات الحكومية، الإنفاق الحكومي، المملكة العربية السعودية. 